\title{
An Investigation of the Relationship between Managers' Effective Leadership Behaviors and Employees' Organizational Commitment Levels
}

\author{
Ahmet Yildirim $^{1, *}$, Erkaya Yirik ${ }^{2}$, Mustafa Çelikten $^{3}$, Yeliz Çelikten $^{4}$ \\ ${ }^{1}$ The Bohdan Khmeknytsky National University, Cherkassy, Ukraine \\ ${ }^{2}$ Governor, Elazig Governorship, Elazig, Turkey \\ ${ }^{3}$ Faculty of Education, Erciyes University, Kayseri, Turkey \\ ${ }^{4}$ Keykubat Anatolian Imam Hatip High School, Kayseri, Turkey
}

Received April 22, 2020; Revised June 16, 2020; Accepted June 29, 2020

Copyright $\bigcirc 2020$ by authors, all rights reserved. Authors agree that this article remains permanently open access under the terms of the Creative Commons Attribution License 4.0 International License

\begin{abstract}
The purpose of the present study is to determine the relationship between institution managers' effective leadership behaviors and institution employees' organizational commitment based on the perceptions of employees working in public institutions. The population of the study comprises of institution employees working in public institutions in the province of Amasya in Turkey in 2020. The sample of study consists of 132 institution employees working in public institutions in Taşova district and selected using random sampling method. While independent $\mathrm{T}$ test was applied to gender, age, marital status, education level and duration of service in the profession variables, One-way ANOVA test was used for the working duration with the last manager as a variable. LSD test was used to determine differences among groups. The findings of the present study suggest that public institution managers display highly effective leadership behaviors. On the other hand, institution employees' organizational commitment levels are above the average. In terms of the perceptions of employees working in public institutions, a positive correlation was found between institution managers' effective leadership behaviors and institution employees' organizational commitment levels. While there was a significant difference in demographic features such as gender, marital status, level of education, working duration of service in the profession and working duration with the last manager, there were no significant differences in terms of age.
\end{abstract}

Keywords Leadership, Effective Leadership, Organization, Organizational Commitment

\section{Introduction}

As the technological changes have gained momentum in recent years, it is becoming more and more difficult for the organizations operating in a constantly competitive environment to be able to sustain their current positions. Their existence largely depends on their capacity to preserve competitive superiority. Being discussed as an important phenomenon in the field of management for years, commitment has never seemed to lose its validity. On the contrary, it has been one of the most studied fields in the existing literature for different professions and yielded different descriptions and perspectives. Whereas the organizational commitment research in the field of organizational behavior dates back earlier times, commitment to work, profession and career have been more popular research topics recently.

Employees' adopting the goals of the organization, their being willing in their efforts to fulfill the activities they will carry out in the direction of these goals and sustainability in their desire for these efforts, that is, organizational commitment of employees has great importance for the organizations. In line with this process, the need for leaders who will make employees a part of the organization and guide them in the direction of organizational goals is increasing. Therefore, the necessity of effective leadership approaches has emerged for today's organizations to be able to be successful and sustain their existence.

\subsection{Leadership}

Humans are social living beings and thus are inclined to work together as a consequence of communal life style rather than an individual one. This undoubtedly brings 
many concepts to the center of human life. In this context, one of the important concepts is leadership as a necessity of the dynamics in social life (Çimen, 2018). Although the definition of leadership is a very old concept, it became a controversial research topic in the 1930s. It is estimated that around three thousand research on leadership had been carried out until 1974. It is thought that this figure exceeded 5000 in the early 1980s. Even though the number of studies on leadership is very hight, it has not been understood completely yet, and thus a large number of theories have so far been proposed on the topic (Ferik, 2001).

When the words "leader" and "leadership" are analyzed from an etymological point of view, the word is derived from Anglo Saxon word "lead", which means road and direction. Leader (lider in Turkish) is defined as a chief, head, guide, advisor or president (Akçakaya, 2010). The word was defined in the written form for the first time in an English dictionary in 1755 as "going in front of a group of people, showing the way". The word leadership (liderlik in Turkish) first appeared in the Webster American Dictionary in 1828 and was defined as "the status and conditions of the leader" (Güçlü, 2016).

The concept of leadership was associated with different meanings from the past to the present due to its dynamic structure. Therefore, it has many different definitions. While Chaudhry and Javed (2012) define leadership as an ability to impress the followers to achieve a specified goal or aim and guide them towards a specific purpose by bringing followers together, Uysal (2016) defines leadership as a responsibility and privilege of managing employees for a specific goal and vision of an organization at a level of different authority and responsibility. Bass and Riggio (2006) view leadership as a set of skills that enable the subordinates to work in collaboration and skills within the boundaries of the organization for a common purpose.

\subsection{Effective Leadership}

Leadership is not just a title. Leadership is related to an individual's personality rather than their activities. Being a leader requires making difficult decisions. If an ordinary behavior is exhibited to the viewers, this leader can be neutralized when $\mathrm{s} / \mathrm{he}$ is about to be liked by everyone. The phrase that leaders are born is not entirely true. There are, of course, some inherent features such as being charismatic. However, many qualities about leadership can be gained at a later time (Krow, 2017).

Effective leadership is characterized by the fact that the viewers are motivated to follow what the leader determines. Successful leaders undoubtedly make people take action. Effective leaders, on the other hand, motivate people to behave in the desired way and move in that direction. Furthermore, effective leaders combine the legal strength of the hierarchical position they have with the natural power provided by the group, use more general supervisory methods and focus on results rather than activities (Aydın, 1994). Managing people requires a number of personal traits such as leadership, administrative skills and cognitive skills, developing abilities to understand the situation in question and displaying behavior accordingly (Strang, 2003). In other words, it is necessary for the manager to manage human relations successfully and motivate his/her subordinates to make the organizational goals come true (Mintzberg, 1973; Schneider, 2002). Leaders need to apply role power, influence, inspire, act as a mentor and a facilitator. Another result is that effective leadership behaviors can be learned and implemented later. Effective leaders are aware of their own behaviors, characteristics, skills, and recognize themselves, organization, groups and relationships among them [14]. In addition, effective leaders are individuals who understand organizational needs and familiarize themselves with the general management structure [15].

An effective leadership requires passion. Effective leaders' dreams and visions are very broad. Leaders who abuse their charismatic effect by serving only their own interests end up being manipulative rather than being effective. However, intellectual, creative and self-confident leaders who care about social values and possess a high vision, communicative and planning competency can achieve great organizational goals by creating a positive effect on their followers through a high interpersonal communication power [16].

Some common features that effective leaders display are mentioned below [17]:

- Listen to the other actively.

- Make constructive suggestions and accepts constructive suggestions.

- Direct correctly.

- Indicate deadlines.

- Make formal and informal presentations.

- Help viewers to make them able to identify and resolve problems.

- Create examples regarding desired behaviors.

- Appreciate others' contributions.

- Are understanding.

- Support the viewers to exchange ideas.

- Consider conflicts.

- Guides the group in goal setting and decision making processes.

- Can delegate responsibilities.

- Ask the group's questions for being answer.

- Create a productive atmosphere.

On the subject of effective leadership, special behavior categories, especially factor analysis, have been discussed. Theoretical deductions and judgmental classifications were used to describe old studies and classifications. In the classification developed by Yukl [18], there are 14 types of behavior categories under Managerial Practices Scale: planning and organizing, problem solving, clarifying roles and objectives, informing, monitoring, motivating and 
inspiring, consulting, delegating, supporting, developing and mentoring, managing conflict and team building, networking, recognizing, and rewarding.

\subsection{Organizational Commitment}

The growing competition power that institutions have experienced in recent years increases the need for employees' effective participation and efforts. Therefore, organizational commitment has been accepted as one of the important fields in management sciences. Organizational Commitment has so far been defined by researchers in different ways according to the organizational context and the researcher's perspective [21].

Becker [22], one of the first researchers who conceptualized organizational commitment from the perspective of employee-organization relationship, states that one needs to renounce some benefits while passing from one institution to another. Sheldon [23] expresses that in the basis of commitment to an institution, the level of employee's relationship with the goals, norms and values of the organization exists [24].

According to Grusky [25], organizational commitment can be defined as the degree of an employee's commitment to the organization. According to Meyer and Allen [26], organizational commitment represents an employee's psychological approach towards an organization, the relationship between the employee and the organization and an individual's free decision to continue their membership in the organization [27]. Commitment is divided into three sub-dimensions as "emotional", "continuity" and "normative". Emotional commitment means an individual's sentimental commitment to an organization through identifying with the organization and remaining in the organization by his/her will and preference. Continuity commitment is associated with an individual's perceived costs of leaving an organization as the employee makes the decision to remain or leave based on the negativity that they will suffer when they leave the organization or benefits of staying in the organization. Normative commitment refers to the perceived imperative to stay in the organization. It is the fact that an employee remains in an organization with a sense of duty and obligation and develops a compulsory commitment [26, 28]. Employees who feel a strong emotional commitment to the organization will stay since they want to stay in the organization. Those who feel a strong continuity commitment will commit because they need the organization. Finally, those who feel a strong normative commitment will remain as they feel liable to the organization. Emotional, continuity and normative commitment must not be as independent categories of organizational commitment. Instead, they must be considered as overlapping elements of organizational commitment [29]. Thus, employees will experience each of these three psychological constructs at different levels. For instance, while some employee can feel the necessity and obligation to remain in the organization, others may not be able to feel it, indicating different psychological situations that affect an employee's commitment to the organization [29].

Organizational commitment is described as an emotional relation which consists of an employee's desire and efforts to achieve organizational goals and success. Loyalty, which is a psychological contract signed between employees and the organization, is explained as the degree of internalizing organizational features and adapting to an organizational perspective. Thus, organizational commitment is an employee's desire to stay in the organization by seeing themselves as a part of the organizational structure and adopting organizational goals and values. In short, it can be regarded as the connection between an employee and organization [30].

Organizational commitment is an employee's power to identify themselves with and be interested in a particular organization [31]. It reflects the binding power that encourages individuals to take part in both organizational and individual actions [32]. According to Wright, Chrstensen and Isett [33], it is significantly related to an employee's compassion for and devotion to organizational goals.

Organizational commitment has a significant positive relationship with job performance [32]. This might be one of the reasons why many organizations look for a reasonable balance between an employee's commitment and organizational performance [34].

Factors significantly related to organizational commitment should be considered. Bulut and Culha [35] report that educational motivation, access to education, advantages of education and support for education positively affect an employee's organizational commitment. Jehanzeb, Rasheed and Rasheed [36] also found an important relationship between organizational commitment and the training of the employees.

It is only possible with employees for an institution to be different from other institutions and ensure its continuity. The organization can make the workforce permanent and provide efficiency by ensuring employees' satisfaction. The relationship between the employee and the organization becomes more important as the staff who occupies an important position in the institutions is needed more in the new management perspectives [37].

\subsection{Literature Review}

\subsubsection{Effective Leadership}

In a study on effective educational leadership, Niece stated that effective educational leaders differed from other managers in three aspects [38]: 1. Effective educational leaders are compatible. They interact with other employees and do not keep themselves out of sight. They do not isolate themselves from the daily school work and interact 
with all individuals in the school frequently. 2. Effective directors maintain their communication with their colleagues at both formal and informal level. 3. Effective educational leaders have managerial practitioners whom they mentor.

Krug [39] found out an important relationship among the dimensions of instructional leadership, defining mission, managing programs and teaching, supervising and supporting teaching, and overseeing students' development and achievement. Blase et al. also observed that effective educational leaders in different regions of the USA were different from other managers at primary, secondary and high schools [38].

Rehman et al. [40] reported in their study that there was a positive relationship between transformational leadership and organizational commitment in terms of leadership styles.

Almutairi [41] concluded that there was a positive significant relationship between the leadership style and organizational commitment as far as the transformational leadership style and employees' emotional commitment are concerned. In a study on leadership dimensions and organizational commitment in 2012, Hulpia et al. [42] concluded that $9 \%$ of teachers' organizational commitment is due to differences between schools.

Today, institution managers' educational leadership roles need to possess some basic features such as vision development, leadership, energy development, acting together and communication [43]. Principals should display a high level of performance in improving educational practices and students' success. This is related to the educational practices and rising students' success standards and the principal's leadership behavior [44, 45, 46, 47, 48]. However, Elmore [49] states that many principals today do not acquire technical management skills to be an effective school manager. Many similar research findings suggest that principals' effective leadership behaviors are not sufficient $[50,51,52,53,54$, $55]$.

\subsubsection{Organizational Commitment}

When studies on the field of education in Turkey are analyzed, it can be observed that different definitions were used for the concept of organizational commitment such as "organizational commitment", "organizational loyalty" or "commitment to the institution". While organizational commitment was expressed by Celep [56] and Sarıdede [57] as "organizational loyalty", some researchers [58, 59] used the term commitment to the institution". Celep [56] found in his study that teachers who devoted themselves to school displayed a higher performance than expected. Çöl [60] reported that academics' level of education increasing was inversely proportional to their emotional and normative commitment to university.

Özgan [61] found moderate and high level positive and meaningful relationships among teachers' perceptions of organizational commitment, executive evaluation and conflict management strategies. Saltık, Ünsar and Oğuzhan [62] reported a relationship between organizational commitment and organizational communication. Kiral [63] revealed that teachers had the perception of the highest emotional and lowest level of continuity commitment and perceived the highest transformational and lowest releasing leadership style in principals.

Allen and Meyer [64] concluded that newly recruited employees had a positive effect on organizational commitment after six months. Meyer, Allen and Smit [29] found out that the dimensions of organizational commitment and professional commitment were not independent from each other in a study on nurse education. Bogler and Somech [65] argued that there were significant relationships among teachers' perceptions of empowerment and professional loyalty, organizational commitment and the perception citizenship. Sharif et al. [66] stated that there was a moderate positive relationship between principals' motivation of employees and teachers' organizational commitment levels. Omidifar [67] concluded that there were distinct and positive relationships between principals' leadership styles and teachers' organizational commitment and job satisfaction. Emrahimi, Zinali and Dodman [68] found positive relationships between emotional intelligence and organizational commitment dimensions. Chirchir et al. [69] reported that teachers perceived the principals' transformational leadership styles more than their interactive leadership style and that there was a positive relationship between principals' transformational leadership characteristics and teachers' emotional and loyalty levels, teachers' general loyalty levels being at a medium level. Xiao and Wilkins [70] revealed that students' satisfaction levels regarding academic achievement and social cohesion were related to the instructors' commitment. However, it was also stated that instructors' commitment to students' social adaptation did not affect the students' perceptions of the quality of education. Han, Yin and Wang [71] observed that the skill avoidance goal affects teachers' commitment to the institution positively and teachers' professional commitment negatively. Dahie, Mohamed and Mohamed [72] reported that transformational leadership and interactive leadership had a positive relationships with organizational commitment, each of which positively affects the academics' commitment. Werang and Pure [73] analyzed the opinions expected to affect and improve teachers' commitment in three categories (teachers' personal characteristics, teachers' working conditions and educational policies). It was observed that similar to Turkey, organizational commitment in the world is one of the most popular research topics with different variables up to date. In various studies at different levels, researchers analyzed the relationship of organizational commitment using variables such as "gender, marital status, age, salary level, seniority, branch, educational status" and "professional commitment, 
job satisfaction, organizational health, organizational commitment, teacher empowerment, organizational citizenship, leadership styles, emotional intelligence."

Existing studies in the literature occupy an important place in the institutional management and in determining the employees' commitment to the institution. The main objective of the present study is to determine the relationship between public institution managers' effective leadership behaviors and institution employees' organizational commitment levels.

In this respect, the sub-questions of the present study can be listed as follows:

1. What are managers' effective leadership characteristics based on to the perceptions of people working in public institutions?

2. What is the organizational commitment level of people working in public institutions?

3. What is the relationship between effective leadership and organizational commitment?

4. Do the effective leadership characteristics of the directors and the organizational commitment levels of the employees differ based on the perceptions of the employees in terms of demographic features (gender, age, marital status, education level, duration of service in the profession and working duration with the last manager).

\section{Materials and Methods}

\subsection{Model}

The research was designed with a relational-screening model. According to Karasar [74] and Frankel, Wallen and Hyun [75], screening models are used when a personality traits or some opinions (such as competence, idea, attitude, belief and knowledge) of a small group that is part of a large group are researched and information is collected from a group of people. The relational screening model does not give a real cause-effect relationship, but it allows the other to be predicted if the situation in one variable is known.

\subsection{Sample}

Research data was collected from 132 people who are working in public institutions and organizations in Taşova, Amasya, Turkey in 2020. The random sampling method was used to determine the research group.

This method is a method that speeds up the research. Because in this method, the researcher chooses a situation that is close and easy to access. This sampling method is often used when the researcher is not able to use other sampling methods [76].

The frequency and percentage distributions depicting the personal characteristics of the group have been demonstrated:

Table 1. Demographic characteristics of participants

\begin{tabular}{|c|c|c|c|}
\hline $\begin{array}{c}\text { Personel } \\
\text { Detail }\end{array}$ & & f & $\%$ \\
\hline \multirow{2}{*}{ Gender } & Female & 76 & 57,6 \\
\hline & Male & 56 & 42,4 \\
\hline \multirow{2}{*}{ Age } & $21-30$ & 48 & 36,4 \\
\hline & $31-40$ & 84 & 63,6 \\
\hline \multirow{2}{*}{ Marital Status } & Married & 72 & 54,5 \\
\hline & Single & 60 & 45,5 \\
\hline \multirow{2}{*}{$\begin{array}{l}\text { Educational } \\
\text { Level }\end{array}$} & Undergraduate & 116 & 87,9 \\
\hline & Graduate & 16 & 12,1 \\
\hline \multirow{2}{*}{$\begin{array}{l}\text { Duration of } \\
\text { Service }\end{array}$} & $1-9$ years & 96 & 72,7 \\
\hline & $10-19$ years & 36 & 27,3 \\
\hline \multirow{3}{*}{$\begin{array}{c}\text { Duration with } \\
\text { the Last } \\
\text { Manager }\end{array}$} & $1-3$ years & 84 & 63,6 \\
\hline & 4-6 years & 36 & 27,3 \\
\hline & $7-10$ years & 12 & 9,1 \\
\hline
\end{tabular}

\subsection{Instrument and Procedures}

In the research, survey technique was used for collecting data. The questionnaire form used in the research consists of three parts. The first section consists of six questions under the name of "Personal Information Form" which includes the demographic variables of the employees. The second part is a scale consisting of a total of nineteen questions prepared under the name of "Effective Leadership Scale of Managers". And the third section includes a scale consisting of eighteen questions to measure the "Organizational Commitment" levels of the employees. The form, which was developed to collect data in the research, consists of 6 (six) questions to learn the gender, age, marital status, level of education, duration of employment in the profession and the duration of employment with the last manager.

The Effective Leadership Scale, which was conducted to determine the effective leadership behaviors of corporate managers according to the perceptions of the employees of the institution, compiled from different resources by Karakaplan Özer and Akdemir [77], was used.

In order to determine the organizational commitment levels of the institution's employees, the 18-item scale, which Meyer and Allen [26] previously developed to measure organizational commitment, was re-tested by Meyer, Allen and Smith [29]. Items 3, 4 and 5 of the scale, which are three-dimensional: emotional, attendance, and normative commitment, are reverse-coded, and the first 6 questions measure emotional commitment, the second 6 questions continuation commitment, and the last 6 questions measurenormative commitment. The scale prepared in the 5-point Likert scale ["I strongly disagree" (1) "I totally agree" (5)] type; There are six items in each dimension. The change intervals of the answers given to 
the scale items were assumed to be equal; Score ranges of the scale: $1.00-1.80$ Strongly disagree (1), 1.81-2.60 Disagree (2), 2.61-3.40 Moderately agree (3), 3.41-4.20 Mostly agree (4) and 4.21-5.00 Totally agree (5) It is rated as.

\subsection{Data Analysis}

The frequency and percentage values of the demographic characteristics of the participants were examined. The normality test was performed to analyze the differences between the participants' opinions and the distribution was found to be normal. Independent $T$ test was used for variables of gender, age, marital status, education level and duration of service in the profession. Parametric One-Way ANOVA test was used to analyze duration with the last manager When the difference was detected as a result of the parametric One-Way ANOVA test, the LSD test, which is a multiple comparison test, was used to detect the difference.

In the study, the Effective Leadership Scale Cronbach's Alpha value was calculated as 81 , while the Organizational Commitment Scale Cronbach's Alpha value was calculated as 70 .

\section{Results}

In this part of the research, the findings obtained as a result of the analyzes made are included.

As can be seen from the Table 2, the effective leadership characteristics of the managers and the organizational commitment sub-dimensions of the employees were above the average according to their perceptions. As a result, it can be said that the employee scores are high.

Table 2. Values of Effective Leadership and Organizational Commitment Sub-dimensions Total Scores

\begin{tabular}{cccccc}
\hline Dimensions & $\mathbf{N}$ & $\overline{\mathbf{x}}$ & $\mathbf{s e}$ & $\mathbf{m i n}$ & $\max$ \\
\hline $\begin{array}{c}\text { Effective } \\
\text { Leadership }\end{array}$ & 132 & 4,14 & 0,07 & 2 & 5 \\
\hline $\begin{array}{c}\text { Emotional } \\
\text { Commitment }\end{array}$ & 132 & 3,29 & 0,08 & 1 & 5 \\
\hline $\begin{array}{c}\text { Attendance } \\
\text { Commitment }\end{array}$ & 132 & 3,42 & 0,09 & 1 & 5 \\
\hline $\begin{array}{c}\text { Normative } \\
\text { Commitment }\end{array}$ & 132 & 3,26 & 0,10 & 1 & 5 \\
\hline
\end{tabular}

It can be seen from the data in Table 3 that there was a statistically significant difference in effective leadership dimension of the managers according to their perceptions and the effective leadership dimension according to the gender variable independent $t$ test results of the organizational commitment sub-dimensions of the employees $(t=-2,231, p<, 05)$. According to this result, it can be said that female employees think that their managers exhibit more effective leadership characteristics than male employees.

When we look at Table 4, there was no statistically significant difference between the effective leadership characteristics of the managers and the organizational commitment sub-dimensions of the employees according to the perceptions of the age variable independent $t$ test results ( $p>, 05)$.

Table 3. Independent $T$ Test Results According to Gender Variable

\begin{tabular}{|c|c|c|c|c|c|c|c|c|c|}
\hline \multirow{2}{*}{ Dimensions } & \multirow{2}{*}{ Gender } & \multirow{2}{*}{$\mathbf{N}$} & \multirow{2}{*}{$\overline{\mathbf{x}}$} & \multirow{2}{*}{ sd } & \multirow{2}{*}{ se } & \multicolumn{4}{|c|}{ Independent $\mathrm{T}$ Test } \\
\hline & & & & & & $\mathbf{t}$ & se & $\mathbf{F}$ & $\mathbf{p}$ \\
\hline \multirow{2}{*}{ Effective Leadership } & Female & 76 & 4,05 & 0,53 & 0,06 & \multirow{2}{*}{$-2,231$} & \multirow{2}{*}{0,08} & \multirow{2}{*}{,949 } & \multirow{2}{*}{, 024} \\
\hline & Male & 56 & 4,25 & 0,46 & 0,06 & & & & \\
\hline \multirow{2}{*}{ Emotional Commitment } & Female & 76 & 3,28 & 0,44 & 0,05 & \multirow{2}{*}{$-0,137$} & \multirow{2}{*}{0,05} & \multirow{2}{*}{9,399} & \multirow{2}{*}{,891 } \\
\hline & Male & 56 & 3,29 & 0,23 & 0,03 & & & & \\
\hline \multirow{2}{*}{ Attendance Commitment } & Female & 76 & 3,49 & 0,48 & 0,05 & \multirow{2}{*}{1,495} & \multirow{2}{*}{0,10} & \multirow{2}{*}{5,119} & \multirow{2}{*}{, 137} \\
\hline & Male & 56 & 3,33 & 0,73 & 0,09 & & & & \\
\hline \multirow{2}{*}{ Normative Commitment } & Female & 76 & 3,35 & 0,51 & 0,05 & \multirow{2}{*}{1,948} & \multirow{2}{*}{0,12} & \multirow{2}{*}{20,28} & \multirow{2}{*}{, 054} \\
\hline & Male & 56 & 3,11 & 0,89 & 0,11 & & & & \\
\hline
\end{tabular}

Table 4. Independent $\mathrm{T}$ Test Results According to Age Variable

\begin{tabular}{|c|c|c|c|c|c|c|c|c|c|}
\hline \multirow{2}{*}{ Dimensions } & \multirow{2}{*}{ Age } & \multirow{2}{*}{$\mathbf{N}$} & \multirow{2}{*}{$\overline{\mathbf{x}}$} & \multirow{2}{*}{ sd } & \multirow{2}{*}{ se } & \multicolumn{4}{|c|}{ Independent T Test } \\
\hline & & & & & & $\mathbf{t}$ & se & $\mathbf{F}$ & $\mathbf{p}$ \\
\hline \multirow{2}{*}{ Effective Leadership } & $21-30$ & 48 & 4,19 & 0,47 & 0,06 & \multirow{2}{*}{0,942} & \multirow{2}{*}{0,09} & \multirow{2}{*}{1,650} & \multirow{2}{*}{,348 } \\
\hline & $31-40$ & 84 & 4,10 & 0,53 & 0,05 & & & & \\
\hline \multirow{2}{*}{ Emotional Commitment } & $21-30$ & 48 & 3,31 & 0,37 & 0,05 & \multirow{2}{*}{0,627} & \multirow{2}{*}{0,06} & \multirow{2}{*}{0,004} & \multirow{2}{*}{, 531} \\
\hline & $31-40$ & 84 & 3,27 & 0,36 & 0,03 & & & & \\
\hline \multirow{2}{*}{ Attendance Commitment } & $21-30$ & 48 & 3,41 & 0,75 & 0,10 & \multirow{2}{*}{$-0,109$} & \multirow{2}{*}{0,10} & \multirow{2}{*}{2,432} & \multirow{2}{*}{,914 } \\
\hline & $31-40$ & 84 & 3,42 & 0,59 & 0,05 & & & & \\
\hline \multirow{2}{*}{ Normative Commitment } & $21-30$ & 48 & 3,29 & 0,79 & 0,11 & \multirow{2}{*}{0,416} & \multirow{2}{*}{0,12} & \multirow{2}{*}{0,105} & \multirow{2}{*}{,678 } \\
\hline & $31-40$ & 84 & 3,23 & 0,65 & 0,07 & & & & \\
\hline
\end{tabular}


Table 5. Independent $T$ Test Results According to Marital Status Variable

\begin{tabular}{|c|c|c|c|c|c|c|c|c|c|}
\hline \multirow{2}{*}{ Dimensions } & \multirow{2}{*}{$\begin{array}{l}\text { Marital } \\
\text { Status }\end{array}$} & \multirow{2}{*}{$\mathbf{N}$} & \multirow{2}{*}{$\overline{\mathbf{x}}$} & \multirow{2}{*}{ sd } & \multirow{2}{*}{ se } & \multicolumn{4}{|c|}{ Independent $\mathrm{T}$ Test } \\
\hline & & & & & & $\mathbf{t}$ & se & $\mathbf{F}$ & $\mathbf{p}$ \\
\hline \multirow{2}{*}{ Effective Leadership } & Married & 72 & 4,19 & 0,48 & 0,05 & \multirow{2}{*}{1,297} & \multirow{2}{*}{0,08} & \multirow{2}{*}{2,227} & \multirow{2}{*}{,197 } \\
\hline & Single & 60 & 4,07 & 0,54 & 0,07 & & & & \\
\hline \multirow{2}{*}{ Emotional Commitment } & Married & 72 & 3,34 & 0,31 & 0,03 & \multirow{2}{*}{1,720} & \multirow{2}{*}{0,06} & \multirow{2}{*}{3,717} & \multirow{2}{*}{, 088} \\
\hline & Single & 60 & 3,23 & 0,41 & 0,05 & & & & \\
\hline \multirow{2}{*}{ Attendance Commitment } & Married & 72 & 3,20 & 0,67 & 0,08 & \multirow{2}{*}{$-5,289$} & \multirow{2}{*}{0,09} & \multirow{2}{*}{15,34} & \multirow{2}{*}{, 000} \\
\hline & Single & 60 & 3,68 & 0,34 & 0,04 & & & & \\
\hline \multirow{2}{*}{ Normative Commitment } & Married & 72 & 2,95 & 0,76 & 0,08 & \multirow{2}{*}{$-6,607$} & \multirow{2}{*}{0,10} & \multirow{2}{*}{8,715} & \multirow{2}{*}{, 000} \\
\hline & Single & 60 & 3,62 & 0,41 & 0,05 & & & & \\
\hline
\end{tabular}

Table 6. Independent $\mathrm{T}$ Test Results According to Educational Level Variable

\begin{tabular}{|c|c|c|c|c|c|c|c|c|c|}
\hline \multirow{2}{*}{ Dimensions } & \multirow{2}{*}{$\begin{array}{l}\text { Education } \\
\text { Level }\end{array}$} & \multirow{2}{*}{$\mathbf{N}$} & \multirow{2}{*}{$\overline{\mathbf{x}}$} & \multirow{2}{*}{ sd } & \multirow{2}{*}{ se } & \multicolumn{4}{|c|}{ Independent $\mathrm{T}$ Test } \\
\hline & & & & & & $\mathbf{t}$ & se & $\mathbf{F}$ & $\mathbf{p}$ \\
\hline \multirow{2}{*}{ Effective Leadership } & Undergraduate & 116 & 4,11 & 0,51 & 0,04 & \multirow{2}{*}{$-1,155$} & \multirow{2}{*}{0,13} & \multirow{2}{*}{0,004} & \multirow{2}{*}{, 250} \\
\hline & Graduate & 16 & 4,27 & 0,50 & 0,12 & & & & \\
\hline \multirow{2}{*}{ Emotional Commitment } & Undergraduate & 116 & 3,24 & 0,32 & 0,03 & \multirow{2}{*}{$-4,096$} & \multirow{2}{*}{0,11} & \multirow{2}{*}{5,088} & \multirow{2}{*}{,006 } \\
\hline & Graduate & 16 & 3,62 & 0,46 & 0,11 & & & & \\
\hline \multirow{2}{*}{ Attendance Commitment } & Undergraduate & 116 & 3,43 & 0,63 & 0,05 & \multirow{2}{*}{0,741} & \multirow{2}{*}{0,07} & \multirow{2}{*}{9,575} & \multirow{2}{*}{,461 } \\
\hline & Graduate & 16 & 3,37 & 0,18 & 0,04 & & & & \\
\hline \multirow{2}{*}{ Normative Commitment } & Undergraduate & 116 & 3,28 & 0,73 & 0,06 & \multirow{2}{*}{1,303} & \multirow{2}{*}{0,18} & \multirow{2}{*}{5,331} & \multirow{2}{*}{, 195 } \\
\hline & Graduate & 16 & 3,04 & 0,39 & 0,09 & & & & \\
\hline
\end{tabular}

Table 7. Independent T Test Results According to the Duration of Service Variable

\begin{tabular}{|c|c|c|c|c|c|c|c|c|c|}
\hline \multirow{2}{*}{ Dimensions } & \multirow{2}{*}{$\begin{array}{l}\text { Duration of } \\
\text { Service }\end{array}$} & \multirow{2}{*}{$\mathbf{N}$} & \multirow{2}{*}{$\overline{\mathbf{x}}$} & \multirow{2}{*}{ sd } & \multirow{2}{*}{ se } & \multicolumn{4}{|c|}{ Independent T Test } \\
\hline & & & & & & $\mathrm{t}$ & $\mathrm{se}$ & $\mathrm{F}$ & $\mathrm{p}$ \\
\hline \multirow{2}{*}{ Effective Leadership } & $1-9$ year & 96 & 4,05 & 0,54 & 0,05 & \multirow{2}{*}{$-3,650$} & \multirow{2}{*}{0,08} & \multirow{2}{*}{11,087} & \multirow{2}{*}{, 000} \\
\hline & 10-19 year & 36 & 4,35 & 0,34 & 0,05 & & & & \\
\hline \multirow{2}{*}{ Emotional Commitment } & $1-9$ year & 96 & 3,28 & 0,40 & 0,04 & \multirow{2}{*}{$-0,419$} & \multirow{2}{*}{0,07} & \multirow{2}{*}{2,260} & \multirow{2}{*}{,676 } \\
\hline & 10-19 year & 36 & 3,31 & 0,24 & 0,04 & & & & \\
\hline \multirow{2}{*}{ Attendance Commitment } & $1-9$ year & 96 & 3,39 & 0,62 & 0,06 & \multirow{2}{*}{$-0,884$} & \multirow{2}{*}{0,11} & \multirow{2}{*}{0,230} & \multirow{2}{*}{,378 } \\
\hline & 10-19 year & 36 & 3,50 & 0,53 & 0,08 & & & & \\
\hline \multirow{2}{*}{ Normative Commitment } & 1-9 year & 96 & 3,27 & 0,68 & 0,06 & \multirow{2}{*}{0,328} & \multirow{2}{*}{0,14} & \multirow{2}{*}{4,682} & \multirow{2}{*}{, 744} \\
\hline & 10-19 year & 36 & 3,22 & 0,78 & 0,13 & & & & \\
\hline
\end{tabular}

As seen in Table 5, according to the perceptions of the employees, there was a statistically significant difference between the effective leadership characteristics of the managers and the marital status variable of the organizational commitment sub-dimensions of the employees according to the independent $t$ test results $(t=$ $-5,289 /-6,607), p<, 05)$. According to this result, single employees showed higher participation than married employees. In this case, it can be said that single employees need the institution and feel compulsory towards the institution.

According to Table 6, according to the perceptions of the employees, there was a statistically significant difference between the effective leadership characteristics of the managers and the educational level variable of the organizational commitment sub-dimensions of the employees according to the independent $t$ test results $(t=$
$-4.096, \mathrm{p}<, 05)$. Accordingly, it can be said that the employees who have a graduate degree stay because they want to stay in the institution by showing higher participation than the employees who have a undergraduate degree.

When Table 7 is analyzed, there is a statistically significant difference in effective leadership dimension according to the perceptions of the employees according to the effective leadership characteristics of the managers and the organizational commitment sub-dimensions of the employees' total duration of service in the profession independent $t$ test results $(t=-3,650, p<, 05)$. Accordingly, it can be said that employees with 10-19 years of professional service period think that their managers exhibit more effective leadership qualities than employees with 1-9 years. 

and Employees' Organizational Commitment Levels

Table 8. One-way ANOVA Test Results According to the Duration with the Last Manager

\begin{tabular}{|c|c|c|c|c|c|c|c|c|c|c|}
\hline Dimensions & $\begin{array}{c}\text { Duration } \\
\text { with the } \\
\text { Last } \\
\text { Manager }\end{array}$ & $\mathbf{N}$ & $\overline{\mathbf{x}}$ & sd & Groups & $\begin{array}{l}\text { Sum of } \\
\text { Squares }\end{array}$ & df & $\begin{array}{c}\text { Mean } \\
\text { Squares }\end{array}$ & $\mathbf{F}$ & $\mathbf{p}$ \\
\hline \multirow{4}{*}{$\begin{array}{c}\text { Effective } \\
\text { Leadership }\end{array}$} & $1-3$ year & 84 & 4,09 & 0,50 & Between & 0,83 & 2 & ,417 & \multirow{4}{*}{1,586} & \multirow{4}{*}{,209 } \\
\hline & 4-6 year & 36 & 4,16 & 0,54 & Within & 33,869 & 129 & ,263 & & \\
\hline & 7-10 year & 12 & 4,36 & 0,44 & Total & 34,702 & 131 & & & \\
\hline & Total & 132 & 4,13 & 0,51 & & & & & & \\
\hline \multirow{4}{*}{$\begin{array}{c}\text { Emotional } \\
\text { Commitment }\end{array}$} & $1-3$ year & 84 & 3,29 & 0,36 & Between & 0,52 & 2 & ,262 & \multirow{4}{*}{1,975} & \multirow{4}{*}{, 143 } \\
\hline & 4-6 year & 36 & 3,35 & 0,40 & Within & 17,041 & 129 & ,232 & & \\
\hline & $7-10$ year & 12 & 3,11 & 0,08 & Total & 17,563 & 131 & & & \\
\hline & Total & 132 & 3,29 & 0,36 & & & & & & \\
\hline \multirow{4}{*}{$\begin{array}{c}\text { Attendance } \\
\text { Commitment }\end{array}$} & $1-3$ year & 84 & 3,44 & 0,71 & Between & 0,88 & 2 & ,442 & \multirow{4}{*}{1,222} & \multirow{4}{*}{,298 } \\
\hline & 4-6 year & 36 & 3,46 & 0,29 & Within & 46,691 & 129 & ,362 & & \\
\hline & $7-10$ year & 12 & 3,16 & 0,37 & Total & 47,576 & 131 & & & \\
\hline & Total & 132 & 3,42 & 0,60 & & & & & & \\
\hline \multirow{4}{*}{$\begin{array}{c}\text { Normative } \\
\text { Commitment }\end{array}$} & $1-3$ year & 84 & 3,38 & 0,79 & Between & 5,14 & 2 & 2,574 & \multirow{4}{*}{5,476} & \multirow{4}{*}{, 005} \\
\hline & 4-6 year & 36 & 3,14 & 0,46 & Within & 60,649 & 129 &, 470 & & \\
\hline & 7-10 year & 12 & 2,72 & 0,21 & Total & 65,798 & 131 & & & \\
\hline & Total & 132 & 3,25 & 0,70 & & & & & & \\
\hline
\end{tabular}

Table 9. LSD Test Results According to the Duration with the Last Manager

\begin{tabular}{|c|c|c|c|c|c|}
\hline Dependent Variable & $\begin{array}{l}\text { Duration with the } \\
\text { Last Manager } \\
\text { (I) }\end{array}$ & $\begin{array}{c}\text { Duration with } \\
\text { the Last } \\
\text { Manager } \\
\text { (II) }\end{array}$ & Mean Difference & se & $\mathbf{p}$ \\
\hline \multirow{6}{*}{ Normative Commitment } & \multirow{2}{*}{$1-3$ years } & 4-6 years & 0,232 & 0,13 & ,091 \\
\hline & & $7-10$ years & 0,658 & 0,21 &, 002 \\
\hline & \multirow{2}{*}{$4-6$ years } & $1-3$ years & $-0,232$ & 0,13 & ,091 \\
\hline & & $7-10$ years & 0,425 & 0,22 &, 065 \\
\hline & \multirow{2}{*}{$7-10$ years } & $1-3$ years & $-0,652$ & 0,21 &, 002 \\
\hline & & 4-6 years & $-0,425$ & 0,22 &, 065 \\
\hline
\end{tabular}

According to Table 8, a statistically significant difference was determined in the normative commitment sub-dimension according to the one-way ANOVA test results of the manager's effective leadership characteristics and the organizational commitment sub-dimensions total scores of the employees according to the employee working time variable. $(\mathrm{F}=5,476, \mathrm{p}<, 05)$. LSD test is performed to determine which groups are different and shown in Table 9.

According to Table 8, a significant difference between 1-3 years and 7-10 years in favor of 1-3 years was found in the results of the LSD test, which is the manager working time variable of total scores of normative commitment sub-dimension of employees. Accordingly, people who are still at the beginning of the working time with the manager can be said to feel more compulsory towards the institution.

\section{Discussion and Conclusion}

In the present study, the relationship between the institution managers' effective leadership behaviors and institution employees' organizational commitment levels based on the perceptions of the employees working in public institutions was analyzed.

The findings of the present study demonstrated that the employees who participated in the study had a high degree of leadership expectation regarding institution managers' 
positive leadership qualities. Employees' effective perceptions of leadership were high. The participants thought that these leaders could guide people within the context of specific objectives and goals, develop new educational strategies, offer a broader horizon, direct employees by showing excitement and enthusiasm, make strategic decisions and possess relevant managerial knowledge and skills $[78,79]$. In the existing literature, leadership and effective leadership were examined by considering school administrators' leadership skills. [80-87]. This finding contradicts to Cankara [50], Chapman [51], Manges and Wilcox [52], Razi [53], Toker [55], and Elmore [49]. These studies report that effective behavior in leadership is not sufficient, particularly among school principals.

The findings of the present study indicated that the employees displayed a moderate emotional and normative commitment and a high degree of continuity commitment to their organization. Therefore, while employees agreed with their commitment to the institution, their identification with the institution, their stay at the institution by their wish and preference (emotional commitment), their stay at the institution as compulsory (normative commitment) at a moderate level, they agreed with the negativity and benefits of staying at the institution (continuity commitment) at a high level. It is known that employees with a high level of institutional commitment work harder in the organization to achieve institutional goals beyond expectations [88]. In this sense, it can be said that employees who find it valuable to contribute to the success of the organizational goals have a high level of loyalty and emotional commitment. This is considered to affect the quality of their work, i.e. their performance [89, 90]. In a study on Turkish Armed Forces, Özutku [91] reported that participants displayed a moderate level of emotional, continuity and normative commitment to the organization. The findings of this study support the present study. Özgan [61] found moderate to high levels of positive and significant relationships between teachers' perceptions of organizational commitment, executive evaluation and conflict management strategies. Yanık [92] found out that teachers' perceptions of continuity commitment and normative commitment were moderate, while their perceptions of emotional commitment were high. In a study on secondary school teachers and administrators, Yılmaz Doğan [93] reported that teachers' perceptions of emotional commitment were high, whereas their perceptions of continuaity commitment and normative commitment were moderate. In another study examining the relationship between organizational health and organizational commitment based on teachers' perceptions, Tan [94] found a medium-level perception of teachers' compliance and identification associated with organizational commitment, and a high perception of internalization. In a different study on teachers and school administrators by Bayata [95], there was a moderate perception of teachers' compliance with organizational commitment and high perception of internalization and identification. Consequently, the findings obtained from the present study were consistent with the findings of the other studies in the current literature.

According to the findings obtained from the present study, a positive relationship was found between corporate managers' effective leadership behaviors and corporate employees' organizational commitment levels based on the perceptions of the employees working in public institutions. In another study, Karakaplan Özer and Akdemir [77] reported that there was a positively significant relationship between effective leadership and emotional commitment. In other words, positive perceptions of effective leadership are directly proportional to the level of emotional commitment. Kıral [63] found out that teachers had the highest emotional and lowest level of perception of continuity commitment and that they perceive the highest level of the transformative and lowest level of permissive leadership style in principals. Dahie, Mohamed and Mohamed [72] observed that transformative leadership and interactive leadership had positive relationships with organizational commitment and that each had a positive influence on academic allegiances. In addition, in the current literature, Çöl [60], Saltık, Ünsar and Oğuzhan [62], Allen and Meyer [64], Emrahimi, Zinali and Dodman [68], Chirchir et al. [69], Xiao and Wilkins [70] and Han, Yin, and Wang [71] reported that organizational commitment was positively associated with other variables.

When the relationship between institutional managers' effective leadership behaviors and corporate employees' organizational commitment levels is analyzed based on demographic features, significant differences were observed in effective leadership dimension in terms of the gender variable. This finding indicates that the number of women who think that managers exhibit more effective leadership behaviors is higher than men. In a study, Sesveren [96] found no significant differences between genders in terms of the school managers' effective leadership characteristics. Similarly, Gedikoğlu and Bülbül [97], Dağlı [98] and Tahaoğlu and Gedikoğlu [99] did not find report any gender-related significant differences. Effective leaders play a significant role in school development and the success of reforms at schools. While male participants considered managers more competent in some studies conducted on managers' performances and their leadership duties [100, 101, 99], women found managers more competent in other studies [102, 50, 53]. Şekerci and Aypay [103] revealed a better communication between female employees and their managers. There were no differences in the sub-scales of organizational engagement by gender. When the relationship between group managers' effective leadership behaviors and corporate employees' organizational commitment levels is analyzed based that the perceptions of the employees in public institutions are analyzed, no significant differences 
were observed in terms of age, while a significant difference was found in terms of marital status, educational status, continuity, normative and emotional commitment, effective management and duration of service in the professiona. A significant difference was observed in the normative commitment in favor of 1-3 years duration of service with the last manager.

In her study, Özutku [91] did not find any significant differences in the sub-dimensions of organizational commitment in terms of age, thus overlapping the findings of the present study. However, the present study contradicts Sesveren [96] and Razi [53]. Karagöz [104], Beşiroğlu [105], Didin [106] and Tosunoğlu [107] reported that teachers' perception of organizational commitment did not differ in terms of marital status. These findings also contradict the results of the present study. Durna and Eren [108] stated that married people had a higher level of commitment compared to single people. Kurşunoğlu et al. [109] did not report any differences in teachers 'emotional and continuance commitment levels, whereas normative commitment levels varied, supporting the findings o the present study.

As a result, it can be argued that there is a positive relationship between effective leadership and organizational commitment. Employees consider their managers as efficient leaders. Female employees believe managers display more effective leadership behaviors compared to male employees. It can be said that single employees need the institution and feel compulsory commitment towards the institution. Employees with a graduate degree are more committed to their institutions. Increasing professional seniority tends to lead employees to think that their managers exhibit more effective behaviors in leadership. Those who are at the beginning of their profession feel more compulsory towards the institution.

\section{Suggestions}

The findings of the present study clearly demonstrated that the managers' behaviors and employee commitment directly interact with one another. The evaluation of employee responses for the scales of organizational commitment and leadership behaviors in a survey in which the level of employee commitment is quite high may be useful for various organizations in terms of maximizing their employee commitment. While these results are conceptually useful, it should be remembered that the commitment as a phenomenon also depends on various different variables. The present study is only a basis for broader future studies on this context. Future studies which will include other factors affecting organizational commitment and different dimensions of organizational commitment in different organizational structures will greatly contribute to the field. The research can be carried out again by taking different approaches to leadership into account and by selecting different samples.

\section{REFERENCES}

[1] Çimen, B. (2018). The effect of spiritual leadership, organizational culture and organizational silence on school success (Doctoral Thesis). Eskişehir Osmangazi University, Institute of Educational Sciences, Eskişehir. W. Zabierowski, A. Napieralski. Chords classification in tonal music, Journal of Environment Studies, Vol.10, No.5, 50-53.

[2] Ferik, F. (2001). The Effect of Leadership Styles in Business on Employees' Job Satisfaction., Journal of Banking and Finance, 4 (19), 75-79.

[3] Akçakaya, M. (2010). New Leadership Approach in the 21st Century. Ankara: Justice Publishing.

[4] Güçlü, N. (2016). Leadership in Educational Management: Theory, Research and Practice. Ankara: Pegem Academy Publishing.

[5] Chaudhry, A. Q., \& Javed, H. (2012). Impact of Transactional and Laissez Faire Leadership Sty.

[6] Uysal, H. T. (2016). "Employee Leadership Perception and Reverse Mobbing Trend: The Effect of Employee Oriented Leadership". The Journal of International Social Research, 9(47), 933.

[7] Bass, B. M., \& Riggio, R. E. (2006). Transformational leadership. Psychology press.

[8] Krow, E., (2017), Five Qualities to Improve to Be an Effective Leader.

[9] Aydın, M. (2000). Contemporary Educational Supervision. Ankara: Hatiboğlu Publishing.

[10] Aydın, M. (1994). Education Management. Ankara: Hatiboğlu Publishing.

[11] Strang, K. D. (2003). Achieving organizational learning across projects. Paper presented at the PMI North America Global Congress, Baltimore, MD, USA.

[12] Mintzberg, H. (1973). The nature of managerial work. New York: Harper and Raw.

[13] Schneider, M. (2002). Do school facilities affect academic outcomes? Washington, DC: National Clearinghouse for Educational Facilities.

[14] Strang, D. K. (2007). Examining effective technology project leadership traits and behaviours. Computers in Human Behaviours, 23, 424-462.

[15] Johnston, W. S. (2003). Faculty governance and effective academic administrative leadership, new directions for higher education. Wiley Periodicals, 124, 57-63.

[16] McNamara, C. (2017). Field guide to consulting and organizational development with nonprofits.

[17] Gordon, T. (1998). Effective Leadership. Success by Design Building Strong Organizations Strong Communities, (p. $1-5)$. 
[18] Yukl, G. (1989), Leadership in Organizations (2nd Ed.), Englewood Cliffs, NJ: Prentice Hall.

[19] Kim, H., \& Yukl, G. (1995), Relationships of Self-Reported and Subordinate- Reported Leadership Behaviors to Managerial Effectiveness and Advancement, Leadership Quarterly 6, 361-377.

[20] Yukl, G., Wall, S., \& Lepsinger, R. (1990), Preliminary Report on Validation of the Managerial Practices Survey, In K.E. Clark \& M.B. Clark (Eds), Measures of Leadership, 223-238, West Orange, NJ: Leadership Library of America.

[21] Lizote, S. A., Verdinelli, M. A., \& do Nascimento, S. (2017). Organizational commitment and job satisfaction: a study with municipal civil servants. RAP: Revista Brasileira De Administração Pública, 51(6).

[22] Becker, H. S. (1960). Notes on the concept of commitment. Amwican Journal of Sociology, 66, 32-42.

[23] Sheldon, M. E. (1971). Investments and involvements as mechanisms producing commitment to the organization. Administrative science quarterly, 143-150.

[24] Ghaffar, R. ve Khan, A. M. (2017). Exploring the level of job embeddeness among college faculty. Journal of Arts and Social Science, II(IV), 22-35

[25] Grusky, O. (1966). Career mobility and organizational commitment. Administrative Science Quarterly, 488-503.

[26] Meyer, J. P. \& Allen, N. J. (1990). A three-component conceptualization of organizational commitment. Human resource management review, 1(1), 61-89.

[27] Taşliyan, M. \& Pekkan, N. Ü. (2017). A Study on the Demographic Characteristics and Organizational Commitment Levels of Employees: The Example of Five Star Hotels, Journal of Organization and Management Sciences, Volume 9, Number 1.

[28] Erdil, O., \& Keskin, H. (2003). Relationships between empowerment and job satisfaction, job stress and organizational commitment. Journal of IU Faculty of Business Administration, 1, 32.

[29] Meyer, J. P., Allen, N. J., \& Smith, C. A. (1993). Commitment to organizations and occupations: Extension and test of a three-component conceptualization. Journal of applied psychology, 78(4), 538.

[30] Meydan, C. H., Basım, H. N., \& Çetin, F. (2011). Organizational justice perception and the effect of organizational commitment on burnout: A research in the Turkish public sector. Turkish World Journal of Social Sciences, 57, 175-200.

[31] Markovits, Y., Davis, A. J., Fay, D., \& Dick, R. V. (2010). The link between job satisfaction and organizational commitment: Differences between public and private sector employees. International Public Management Journal, 13(2), 177-196

[32] Trivellas, P. (2011, December). Work motivation and job performance of frontline employees: the mediating role of organizational commitment. In 2011 IEEE International Conference on Industrial Engineering and Engineering Management (pp. 1878-1882). IEEE

[33] Wright, B. E., Christensen, R. K., \& Isett, K. R. (2013).
Motivated to adapt? The role of public service motivation as employees face organizational change. Public Administration Review, 73(5), 738-747.

[34] Danish, R. Q., \& Usman, A. (2010). Impact of reward and recognition on job satisfaction and motivation: An empirical study from Pakistan. International journal of business and management, 5(2), 159.

[35] Bulut, C., \& Culha, O. (2010). The effects of organizational training on organizational commitment. International Journal of Training and Development, 14(4), 309-322.

[36] Jehanzeb, K., Rasheed, A., \& Rasheed, M. F. (2013). Organizational commitment and turnover intentions: Impact of employee's training in private sector of Saudi Arabia. International Journal of Business and Management, 8(8), 79

[37] Kurtbaş, D. (2011). The relationship between the psychological violence faced by academics and organizational commitment is a research at public and foundation universities. (Master thesis), Gazi University, Institute of Educational Sciences, Ankara.

[38] Calhan, G. (1999). Instructional Leadership of Primary School Principals. (Unpublished Master Thesis). Y1ldiz Technical University: Istanbul.

[39] Krug, S. E. (1992). Instructional leadership: A constructivist perspective. Educational administration quarterly, 28(3), 430-443.

[40] Rehman, S.U., Shareef, A., Mahmood, A. \& Ishaque, A. (2012). Perceived leadership styles and organızational commitment. Interdisciplinary Journal of Contemporary Research in Business, 4(1), 616-626.

[41] Almutairi, D. O. (2013). The relationship between leadership styles and organizational commitment: a test on saudi arabian airline. World Review

[42] Hulpia, H., Devos, G., Rosseel, Y., \& Vlerick, P. (2012). Dimensions of distributed leadership and the impact on teachers' organizational commitment: a study in secondary education. Journal of applied social psychology, 42(7), 1745-1784.

[43] Matters, P. (2005). Future school leaders: who are they and what are they doing? expect the unexpected, Australian AARE Conference, Center For Educational Studies, Sydney Australia.

[44] Hallinger, P. \& Murphy, J. (1991). Developing leaders for tomorrow's schools. Phi Delta Kappan, 72(7), 514-520.

[45] Hausman, C., Crow, G., \& Speery, D. (2000). Portrait of the ideal principal: context and self. NASSP Bulletin, 84(617), $5-14$.

[46] Milstein, M. (1993). Changing the way we prepare educational leaders. New York: Teachers College Press.

[47] Salazar, S. P. (2007). Professional development needs of rural principals: a seven state-study. The Rural Educator, 29(3), 20-27.

[48] Tirozzi, G. (2000, February 23). Our time has come: principals my get a share of the federal pie. Education Week, (February 23).

[49] Elmore, R. (2002). Bridging the gap between standards and 
achievement: the imperative for Professional development in education. Washington, DC: Albert Shanker Institute.

[50] Cankara, Ş. (2008). Investigation of effective leadership levels of principals working in vocational high schools. (Master Thesis), Yeditepe University, Istanbul.

[51] Chapman, J. D. (2005). Recruitment, retention and development of school principals, international institute for educational planning. Educational Policy Series, 2, 1-37.

[52] Manges, C. \& Wilcox, D. (1997). The role of the principal in rural school reform. (ERIC Document Reproduction Service No. EJ 545106)

[53] Razi, S. (2003). Contemporary leadership trends of primary school administrators (Van province example). (Unpublished Master's Thesis), Yüzüncü Y1l University, Van.

[54] Taş, A. (2000). The levels of primary school administrators to perform their teaching leadership roles (Example of Burdur-Isparta Provinces). (Unpublished Doctoral Thesis), Gazi University, Ankara.

[55] Toker, T. (2007). The level of realization of expectations and expectations of classroom teachers about school leadership behaviors from school principals. (master's thesis), Hacettepe University, Ankara.

[56] Celep, C. (1998). Organizational Commitment of Teachers in Educational Organizations. Education and Science, 22 (108), 56-62.

[57] Sarıdede, U. (2004). The effect of organizational commitment on the intention to quit in educational organizations. (Master Thesis), Kocaeli University Institute of Social Sciences, Kocaeli.

[58] Nal, K. (2003). A research to determine the relationship between the attitudes of classroom teachers' administrators towards management styles and their commitment to the institution. (Master Thesis), Istanbul University Institute of Social Sciences, Istanbul.

[59] Özsoy, S. A., Ergül, Ș., \& Bay1k, A. (2004). Examination of the commitment status of a college staff. ISGUC The Journal of Industrial Relations and Human Resources, 6 (2).

[60] Çöl, G. (2004). A research on the relationship between empowerment and organizational commitment. (Doctoral Thesis), Gebze Institute of Technology Social Sciences Institute, Kocaeli.

[61] Özgan, H. (2011). Investigation of the Relationship Between Teachers' Perceptions of Organizational Justice, Trust, Loyalty, Executive Evaluation and Conflict Management Strategies in the Context of Organizational Behavior. Educational Sciences: Theory \& Practice, 11 (1), 229-247.

[62] Saltık, B. Ünsar, A. O. ve Oğuzhan, A. (2015). The effect of organizational communication on organizational commitment: A field research. Financial Political \& Economic Comments, 52 (600), 47-58.

[63] Kiral, E. (2017). The Effect of Leadership Styles Perceived by Teachers in Principals on the Level of Organizational Commitment. Abstract Paper. Verbal Notice. IV. International Eurasian Educational Research Congress Bildiri Kitab1. Denizli, 469-470.
[64] Allen, N.J. \& Meyer, J.P. (1990). The measurement and antecedents of affective, continuance and normative commitment to the organization. The British Psychological Society,63(1),1-18.

[65] Bogler, R., \& Somech, A. (2004). Influence of teacher empowerment on teachers "e organizational commitment, professional commitment and organizational citizenship behavior in schools. Teaching and teacher education, 20(3), 277-289.

[66] Sharif, S., Dullah, J., Osman, K., \& Sulaiman, S. (2010). Headmaster's leadership style and teachers' commitment in Malaysian Rural Primary Schools. International Journal of Learning, 16(12), 229-244.

[67] Omidifar, R. (2013). Leadership Style, Organizational Commitment and Job Satisfaction: A Case Study on High School Principals in Tehran, Iran.American Journal of Humanities and Social Sciences, 1(4), 263-267.

[68] Emrahimi, A., Zinali, S., \& Dodman, K. (2013). Explanation of comoponent of emotional intelligence and organizational commitment: case study of managers and assitants of city public school in Piranshahr. Asian Journal of Social Sciences \& Humanities,2(4), 192-199.

[69] Chirchir, R.K., Kemboi, A., Kirui, W., \& Ngeno, V. (2014). Leadership style and teachers commitment in public primary schools in Bomet County, Kenya. Journal of Education and Practice, 5(39), 175-183.

[70] Xiao, J., \& Wilkins, S. (2015). The effects of lecturer commitment on student perceptions of teaching quality and student satisfaction in Chinese higher education. Journal of Higher Education Policy and Management,37(1), 98-110.

[71] Han, J., Yin, H., \& Wang, W. (2016). The effect of tertiary teachers ${ }^{\text {ee }}$ goal orientations for teaching on their commitment: The mediating role of teacher engagement. Educational Psychology,36(3), 526-547.

[72] Dahie, A. M., Mohamed, A. A., \& Mohamed, R. A. (2017). Leadership style and organizational commitment: Case study from University of Somalia. International Journal of Engineering Science, 14838.

[73] Werang, B. R., \& Pure, E. A. G. (2018). Designing strategy for improving teacher's organizational commitment in the remote elementary schools of Merauke district, Papua, Indonesia. International Journal of Research Studies in Education, 7(1), 15-28.

[74] Karasar, N. (2006). Scientific research method (16th edition). Ankara: Nobel Publications.

[75] Frankel, R. J., Wallen, E. N. \& Hyun, H. H. (2011). How to design and evaluate research in education (8th Edition). New York: McGraw-Hill.

[76] Büyüköztürk, Ş., Kılıç Çakmak, E., Akgün, Ö. E., Karadeniz, Ş., \& Demirel, F. (2012). Sampling Methods. University of Balikesir.

[77] Karakaplan Özer, E. \& Akdemir, B. (2019). Mediating effect of employer brand perception in the relationship between effective leadership and emotional commitment and a research. (Ph.D. Thesis), İnönü University, Institute of Social Sciences, Malatya. 
[78] Aksel, İ. (2003). Effects of leadership behaviors of business managers on job satisfaction and an application (Master Thesis). Thesis No: 140630. Pamukkale University: Denizli.

[79] Eren, E. (2001). Management and organization (contemporary and global approaches). İstanbul: Beta Publishing Distribution A.P.

[80] Abbaspour, M., Heydarinejad, S. \& Azmsha, T. (2012). "Comparative study of relation between principal's leadership styles and organizational commitment of physical education teachers. International Journal of Sport Studies, 2(4), 186-192.

[81] Buluç, B. (2009). The relationship between the school principals' leadership styles and organizational commitment according to the perceptions of classroom teachers. Educational Administration: Theory and Practice, 57 (57), 5-34.

[82] Yilmaz, A., \& Ceylan, Ç. B. (2011). The relationship between the leadership behavior levels of primary school administrators and teachers' job satisfaction. Journal of Educational Management in Theory and Practice, 17 (2), 277-394.

[83] Dereli, M. (2003). A survey research of leadership styles of elementary school principlas (Master Thesis). Thesis No: 140148. Middle East Technical University: Ankara.

[84] Thomas, K. (2002). Perceptions regarding leadership orientations of local school board chairpersons in the Commonwealth of Virginia. Unpublished doctoral dissertation, State University, Faculty of Virginia Polytechnic Institute, Virginia.

[85] Poniatowski, D. (2006). The relationship of student achievement to principals' self-reported use of the four frame theory. Unpublished doctoral dissertation, University of Central Florida, College of Education, Florida.

[86] Madenoğlu, C., Uysal, Ş., Sarıer, Y., \& Banoğlu, K. (2014). The relationship between school principals 'ethical leadership behaviors and teachers' job satisfaction with organizational commitment. Journal of Educational Management in Theory and Practice, 20 (1), 47-69.

[87] Turan, S., \& Ebiçlioğlu, N. (2002). Evaluation of the leadership characteristics of school principals in terms of gender. Educational Administration: Theory and Practice, 31 (31), 444-458.

[88] Jones, G. R., \& George, J. M. (2003). Contemporary Management (Second edition). New York: McGraw-Hill/ Irwin.

[89] Huselid, M. A., \& Day, N.E. (1991). Organizational commitment, jobinvolvement and turnover:A substantive and methodological analysis. Journal of Applied Psychology, 76(3), 380-391.

[90] Dubrin, A. J. (2006). Essentials of Management (Sekizinci bask1). Thomson: South-Western.

[91] Özutku, H. (2008). Examining the relationship between emotional, continuity and normative commitment to organization and work performance. Istanbul University Faculty of Business Journal, 37 (2), 79-97.

[92] Yanık, F. (2018). Investigation of the Relationship Between Special Education Teachers' Perceived Effective Leadership
Traits and School Loyalty Levels towards Their Administrators. (Master Thesis, Istanbul Kultur University / Institute of Social Sciences / Department of Educational Sciences). Thesis No: 507979.

[93] Yilmaz Doğan, M. (2017). Organizational commitment levels of secondary school teachers and administrators (Master Thesis). Thesis No: 486449. Dokuz Eylul University: Izmir.

[94] Tan, S. (2017). Examining the relationship between organizational health and organizational commitment according to teacher perceptions (Master Thesis). Thesis No: 462081. Siirt University: Siirt.

[95] Bayata, G. (2017). Examining the relationship between the democratic attitudes of school principals and teachers' organizational commitment levels according to the opinions of teachers (Master Thesis). Thesis No: 451205. Atatürk University: Erzurum.

[96] Sesveren, S. (2015) Investigation of the Relationship between School Leaders' Effective Leadership Traits and Subjective Well-Being Levels. (Master Thesis). Thesis No: 418054. Erciyes University, Institute of Educational Sciences, Kayseri.

[97] Gedikoğlu, T., \& Bülbül, S. (2009). Managerial competencies of primary school principals in terms of leadership standards belief dimension. National Education Journal, 182 (38), 123-149.

[98] Dağl1, A. (2010). Learning Leadership Behavior of General High School Principals. Electronic Journal of Social Sciences, 9(31).

[99] Tahaoğlu, F., \& Gedikoğlu, T. (2009). Leadership roles of primary school principals. Educational Administration: Theory and Practice, 58 (58), 274-298.

[100]Can, N. (2007). Determination of how effective management behaviors of primary school principals are evaluated by teachers. (master's thesis). Yeditepe University, Istanbul.

[101] Gökyer, N. (2010). The levels of primary school principals performing their teaching leadership roles and factors limiting these roles. Selcuk University Ahmet Keleşoğlu Faculty of Education Journal, 29,113-129.

[102] Bayraker, B. (2003). Instructional leadership behaviors of primary school principals (Denizli example). (Unpublished master's thesis). Pamukkale University, Denizli.

[103] Şekerci, M., \& Aypay, A. (2009). Relationship between primary school administrators' management skills and group effectiveness. Educational management in theory and practice, 57 (57), 133-160.

[104] Karagöz, A. (2008). The Relationship Between Ethical Leadership Roles Perceived by Teachers of Primary and Secondary School Administrators and Teachers' Organizational Commitment (Bursa Province Example). (Master Thesis), Yeditepe University Institute of Social Sciences, Istanbul.

[105] Beşiroğlu, A. (2013). The Relationship of the Leadership Styles of the Administrators of Secondary Education Institutions with Organizational Commitment. (Master Thesis). Marmara University Institute of Educational Sciences, Istanbul. 
[106] Didin, N., S.. (2014). The Relationship Between Leadership Styles of Administrators in Official and Private Basic Education Institutions and Organizational Commitment of Teachers and Examination According to Some Demographic Variables. (Master Thesis), Gazi University Institute of Educational Sciences, Ankara.

[107] Tosunoğlu, H. (2014). The Mediating Role of Trust in Organizations in the Impact of Leadership Style Perception on Organizational Commitment. A Case Study. (Master Thesis). Hacettepe University, Ankara.

[108] Durna, U., \& Eren, V. (2005). Organizational Commitment on the Three Commitment Axes. Doğuş University Journal, $6(2), 210-219$.

[109] Kurşunoğlu, A., Bakay, E., \& Tanrı̈ğen, A. (2010). Organizational Commitment Levels of Primary School Teachers. Pamukkale University Journal of Education, (28), 101-115. 